\title{
A new type of diamondiferous kimberlite of the Zimny Bereg area (pipe named after Vladimir Grib)
}

\author{
Verichev, E.M. ${ }^{1}$, Sablukov, S.M. ${ }^{2}$, Sablukova, L.I. ${ }^{2}$ and Zhuravlev, D.Z. ${ }^{3}$ \\ 1. ZAO “ Arkhangelskgeolrazvedka”, Arkhangelsk district, Novodvinsk 163000, Russia. \\ 2. Central Research Institute of Geological Prospecting (TsNIGRI), Varshavskoe shosse, 129b, Moscow 113545, Russia \\ 3. Institute of Ore Deposits (IGEM) Russian Academy of Sciences, Staromonetny per., 35, Moscow 109017, Russia
}

Kimberlitic rocks of the Zimny Bereg area (the Arkhangelsk diamondiferous province) are grouped in two series, which are different in their petrography, mineralogy, geochemistry and isotope characteristics (Sablukov, 1990; Makhotkin and Zhuravlev, 1993). Rocks of the Al-series form a row from diamondiferous kimberlites of the Zolotitsa cluster (the Lomonosov diamond deposit) to kimmelilitites and olivine melilitites of the Verhotina, Suksoma, Chidvia and Izhma river basins. Rocks of the Fe-Ti series form a row from poorly diamondiferous Pachuga kimberlites to kimpicrites and melilitic picrities of the Shocha, Kepina, Soyana and Megra river basins.

In February 1996, a new diamondiferous kimberlite pipe was discovered in Zimny Bereg. The rocks of the pipe Anomaly 441, which was named after Vladimir Grib, have a unique composition in the whole complex of volcanic rocks of this region.

The geological structure of the Vladimir Grib pipe is similar to that of weakly eroded volcanic pipes of this region. It has a well-marked crater zone, 90 to $130 \mathrm{~m}$ thick, composed of subhorizontal layers of various rocks, from quartzose clayey sandstones and sedimentary rock breccias to tuffites and tuffs of kimberlites. A vent zone is made up of rocks that are related to two intrusion phases. The rocks of the first phase (xenotuffs and xenotuffites) form a relic in the southern part of the pipe. The vent zone is composed mainly of homogeneous, massive kimberlitic tuffisites (second intrusion phase).

A probable age of the Vladimir Grib pipe is estimated as Late Devonian, the same as that of the other Zimny Bereg volcanic pipes. This dating was based on the findings of a Leptophleum sp. plant in tuff sandstones of the crater zone (dating made by A.L.Yurina, Moscow State Lomonosov University).

Petrography. The rocks of the Vladimir Grib pipe are various structural and textural varieties of micaceous kimberlites. Kimberlitic tuffisites have a litho-crystalloclastic texture and a massive structure. They are composed of oval macrocrystals of olivine (40\%) and phlogopite (2\%), of nuclear- or film-type kimberlitic autoliths (5-12\%), of rare, angular-concave, silt xenoliths (1-2\%), of granulites $(1 \%)$ and of microscaly serpentine cement $(45 \%)$. Autoliths are composed of olivine (macrocrystals: $5-10 \%$, phenocrystals: $20-30 \%$ ), phlogopite (1-5\%) and a matrix which is made up of a serpentine + carbonate + phlogopite aggregate with impregnated opaques (ilmenite, magnetite, perovskite and chrome spinel). Inclusions of rutile microcrystals occur universally in zones of growth of olivine phenocrysts.

Geohemistry. The kimberlitic rocks of the Vladimir Grib pipe are highly ultramafic, i.e., rich in $\mathrm{Mg}, \mathrm{Co}, \mathrm{Cr}, \mathrm{Ni}$ and poor in $\mathrm{Fe}, \mathrm{Sc}, \mathrm{Si}, \mathrm{Al}, \mathrm{Ca}$. The rocks are $\mathrm{K}$-rich, with $\mathrm{K}_{2} \mathrm{O} / \mathrm{Na}_{2} \mathrm{O}$ varying from 1,5-3 in autoliths to 1 in tuffisites. Among incompatible elements, $\mathrm{TiO}_{2}$ and $\mathrm{Ta}$ occur in high 
concentrations, $\mathrm{Nb}$ content is moderate, and concentrations of $\mathrm{Zr}, \mathrm{Hf}, \mathrm{Th}, \mathrm{U}, \mathrm{Rb}, \mathrm{Sr}, \mathrm{Ba}, \mathrm{LREE}$ and other elements are low.

High-pressure minerals are abundant in the Vladimir Grib pipe. Picroilmenite and pyrope prevail there, while chrome-diopside, phlogopite, diopside and orthopyroxene occur in minor amounts, and chrome spinel was found very rarely. Minerals of ultramafic association are high-magnesian and high-chromian.

Mantle xenoliths occur in the Vladimir Grib pipe more frequently than in any other pipe of the region. They are rather large, up to $10-18 \mathrm{~cm}$, and are represented by pyrope dunites, pyrope peridotites, eclogites, illmenite peridotite and various garnet-clinopyroxene-phlogopite metasomatites. Spinel dunites and peridotites, which are typical of diamondiferous pipes of the Zolotitsa cluster, occur here very rarely.

$\mathrm{Nd}-\mathrm{Sr}$ isotope characteristics of the new pipe rocks (corrected for $370 \mathrm{Ga}$ ) are as follows: $\varepsilon_{\mathrm{Sr}}(\mathrm{t})=$ +4.1 and $+11.3 ; \varepsilon_{\mathrm{Nd}}(\mathrm{t})=-0.1$ and +0.9 , which is similar to $\mathrm{Nd}-\mathrm{Sr}$ parameters of Fe-Ti series kimberlitic rocks of the Zimny Bereg area and Group 1 South African kimberlites.

Petrography, mineralogy, geochemistry and isotope characteristics of the rocks from the Vladimir Grib pipe indicate that these rocks belong to Fe-Ti kimberlite series of this region. The rocks are similar to diamondiferous kimberlites of southern regions of Yakutia (Daldyno-Alakit and MaloBotuobiya areas), as well as to Group 1 South African kimberlites.

Conclusions. The Vladimir Grib pipe is composed of diamondiferous kimberlites of a specific type which is new to Zimny Bereg. The rock belongs to the most ultramafic, diamondiferous variety of a Fe-Ti kimberlite series which is most similar to mantle substratum rocks in its modal and geochemical composition (Figures 1 and 2). No occurrences of rocks belonging to this row of Fe-Ti series were known earlier in the Zimny Bereg, but their presence was inferred by analogy with kimberlites of the Yakutian province. Zimny Bereg is a unique diamond-bearing region, where two full rows of Late Devonian kimberlitic rocks (differentiated from highly diamondiferous kimberlites to non-diamondiferous melilitites and picrites) occur and basaltic volcanic pipes of the same age are present.

The work was supported by Archangel Diamond Corporation (Canada) and Russian Foundation for Basic Research (project No 96-05-65827).

\section{References}

Sablukov, S.M., 1990, On petrochemical series of kimberlite rocks: Dokl. Akad. Nauk USSR, V. 313, No. 4, p. 935-939 (in Russian).

Makhotkin,I.L. and Zhuravlev,D.Z., 1993, Sr and Nd isotope composition of the Arkhangelsk region diamondiferous kimberlites and melilitites: Dokl. RAN, V. 332, N 4, p. $562-567$ (in Russian). 


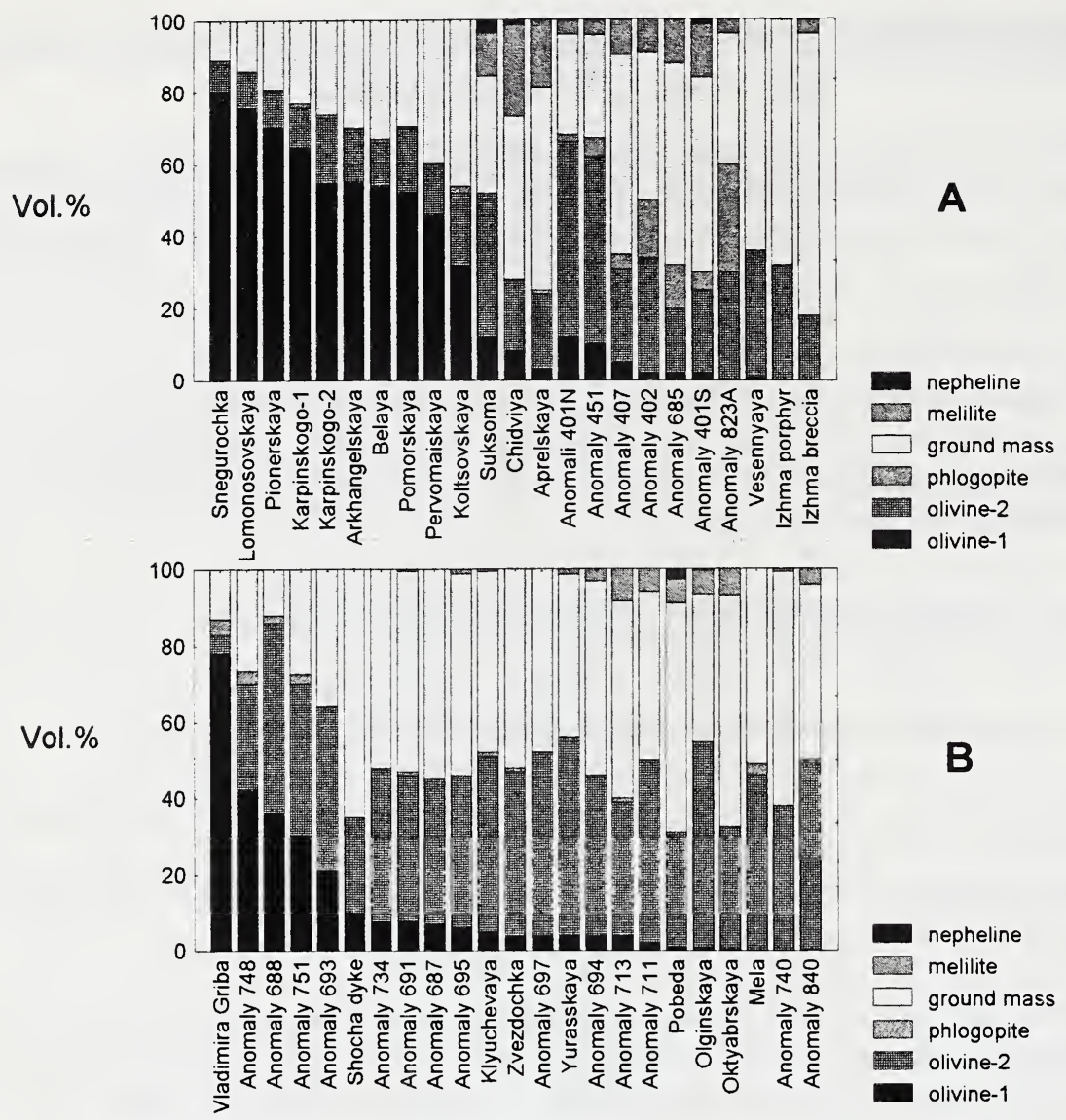

Figure 1. Modal composition of the Zimny Bereg Al-series (A) and Fe-Ti-series (B) kimberlite rocks

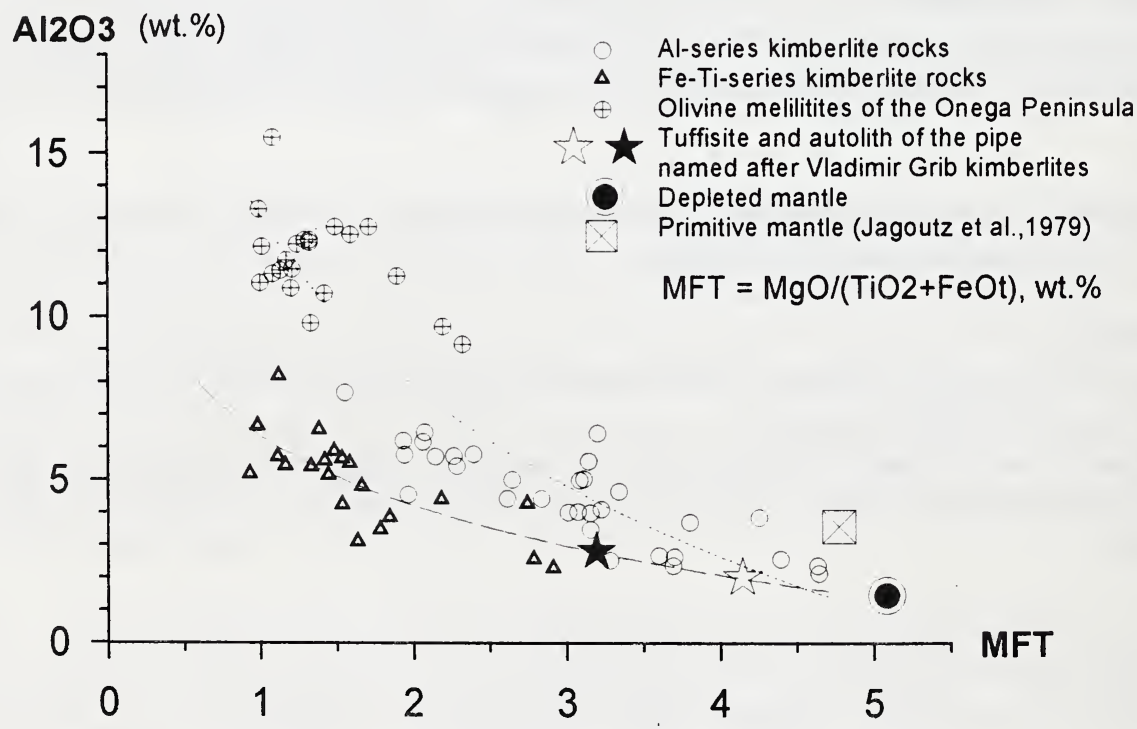

Figure 2. Chemical composition of the Zinmy Bereg kimberlite rocks 